\title{
ANALYSIS OF WATER POVERTY FOR IREPODUN LOCAL GOVERNMENT AREA (KWARA STATE, NIGERIA)
}

\begin{abstract}
In the wake of a growing concern about the unchecked rise of poverty and the consequences of water scarcity, the relationships between water and poverty form an object of a sprawling literature. This research seeks to study access to rural water supply in Irepodun Local Government Area (LGA), Kwara State. Data were sourced from the 11 wards in the LGA. Twenty households were sampled per ward; altogether 220 households were sampled in this study. Access
\end{abstract} to water was estimated using Water poverty index (WPI) computed after Sullivan and Meigh [2006] using household data; based on 5 sub-components: resources, accessibility, capacity, uses and environment. Resources was seen to be high generally, with highest in Omu Aran ward I (93 \%), accessibility was highest in Oro I (71\%), capacity was generally weak (highest score was $43 \%$ in Omu Aran III), uses was highest in Omu Aran II and in Oko, environment was highest in Ipetu-RoreAran Orin ward (63\%.).Water poverty index (WPI) was least (47\%) in Oko ward, while the highest (62\%) was obtained at Ipetu-RoreAran Orin ward. Only 2 LGAs namely: Oko and Arandun wards are water poor, all other wards have above average scores. However, the seemingly high scores are mainly due to the relatively high mean annual rainfall (MAR) and the efforts of Community Based Associations (CBA) which is typical of Kwara south senatorial districts of Kwara state which has long history of CBAs and Town Unions dating back into about 100years. Hence, there is need for government and public-private intervention in water provision; particularly in Oko and Arandun wards in view of their low capacities and few sources of water as locals will have low capacities to explore alternative sources of water. Conclusively, access to water in Irepodun LGA is appreciably high. However, the challenges of increasing population and urbanization suggest needs for expanding water resources infrastructures in the LGA.

KEY WORDS: Water Poverty, Income Poverty, Accessibility, Capacity, Uses, Environment, Resources

\section{INTRODUCTION}

Water poverty index is a combined measure of water availability and access. It is a platform for discussing the twin relationship between poverty and shortage of water. The World Water Assessment Program [WWAP, 2001] sees water poverty as the condition of insufficient water of satisfactory quality to meet human and environmental need. WPI is the similitude of the HDI, it is disaggregate in nature and it is suitable for assessing people's water need, particularly in rural households compared to other indices [Alcamo, et al, 1997, 2000; Sekler, et. al. 1998; Vorosmarty, et. al. 2000; Sullivan, 2002; Lawrence et al, 2002; Soussan and Frans, 2003; etc]. The underlying conceptual framework of the index encompass water availability, access to water, capacity for sustaining access, the use of water and the environmental factors which impact on water quality and the ecology which water sustains. One of the challenges of water planners is how to estimate water need of household objectively.

Access to water has become a human right issue and a descriptor of poverty. There 
is a strong link between 'water poverty' and 'income poverty' [Sullivan, 2002]. Poor communities suffer great health burden, due to inadequate water supplies and water management as ill health prevents them from moving out of the poverty cycle and diseases. Indeed, poor household expend a disproportionate part of their income on medical treatment for preventable diseases, such income will not be available for investment and production, little wonder the United Nations MDG canvassed for the provision of potable water as a means of poverty alleviation. A direct relationship exists between poverty and sanitation. Poor households have the heaviest health burden; they frequently live in contaminated and degraded environments where pathogens and toxic chemicals agents are common in water, air and soil. In such environment, services that provide protection for public health, water supply, sanitation and drainage are less developed. In addition, poor people have lower levels of malnutrition; they have likelihood of infectious diseases. The impact of diseases is mostly felt by poor households in the developing world, unlike within the developed world where payment will be made through health insurance or social security; in poor nations safety net is not common. Hence, expenditure on sickness will lead to foregoing other items such as food and education [Soussan and Frans, 2003]. III health will lead to loss of time spent on income generation. According to Rennie and Sighn [1996] the poor of the world depend directly on natural resources such as raw water, streams, river basins, etc.

The nexus between domestic water supply and poverty becomes more threatening when we reflect on these facts: first, that almost 2 in 3 people who need safe dirking water survive on less than 2 dollar a day; second, daily women across the world spend some 200 hours collecting water [WaterAid, 2012]; third, children in poor environment carry 1000 parasitic warms in their bodies at any time [Waterfacts, 2011]; fourth, water and sanitation crises have claimed more lives through diseases than any war through weapons [Waterfacts,2012]; lastly, that, yearly, 1.4 million children die from unavailable clean drinking water of which $98 \%$ lives in developing world.

Nigeria has been listed as one of the countries that will be water stressed in the next decade. According to Moll and Molluga, [2008] water scarcity can be in respect of physical scarcity, economic scarcity, management scarcity, institutional scarcity and political scarcity. In the same vein, Ashton [2002; 2007] have also documented cases of water conflicts induced by water scarcity in Nigeria.

A study of WPI will give an insight to the nature of water problems; assist in monitoring progress made at water provision by local authorities and may serve as a whistle blower on the level of water supply. Further, a direct bearing exist between rural water supply and school enrolment, hence, WPI will give insights to school enrolment and especially the extent of girl child education (both in terms of school enrolment and rate of completion of primary school education). The analysis of water poverty in Irepodun Local Government is of relevance in the following respect; it will: (i) assist in evaluating the state of water supply in the LGA, (ii) provide an insight into water management, (iii) expose the gap in developmental processes as it relates to water supply, (iv)guide government and the communities on their roles in self help projects, (v) showcase water use level of people with a view to assisting in decision making processes and development planning, it will indicate the level of vulnerability of the community to conflicts and finally (vi) results can be interpolated to areas where such analysis has not been previously conducted.

This work is aimed at analyzing water accessibility via water poverty index at the household level in Irepodun Local Government area of Kwara State. 


\section{STUDY AREA}

Nigeria is a federation with 3 tiers of government, which are federal, states and LGAs, Nigeria comprises of 36 states and 774 LGAs. This is to make governance close to the ordinary citizen. Nigeria has a population of 167 million and a landmass of $910,770 \mathrm{~km}^{2}$. Irepodun LGA is one of the 774 LGAs in Nigeria and one the 16 LGAs in Kwara state. Irepodun LGA has an area of $737 \mathrm{~km}^{2}$ and a population of 148,610 people (2006 census).

According to the data released by the World Bank in 2014, average precipitation in Nigeria is $1,150 \mathrm{~mm}$, the percentage of annual domestic fresh water withdrawal in Nigeria is 31 billion cubic meters, GDP water use is 16 dollar per cubic meters. Also, access to improved water supply in the rural areas in Nigeria is $49 \%$, while internal renewable fresh water resource is 1,346 cubic meters and access to improved water sources between 2009 and 2013 in Nigeria is $64 \%$. According to the same report, GDP per capita is 3,010 US Dollar and $84 \%$ of land is under agriculture. Primary school completion rate is $76 \%$ and ratio of boys to girls in school enrolment is $91 \%$ while under five mortality is 124 per 1000 live birth.

Irepodun LGA has an alternating climate of wet and dry seasons; wet season last for six months (April to November) with about 1100-1500 mm of rainfall. Dry season starts in November and last in April. Wet season is accompanied by the south westerly wind which originates from the Atlantic Ocean, while dry season is characterized by harmattan wind, which is a dry wind. The area has savannah vegetation characterized by grasses and trees. Irepodun LGA has undulating hills within the older basement complex rocks the area is drained by short swift flowing streams which are mostly seasonal. River Oshin is the principal drainage line.

\section{METHODS OF STUDY}

Accessibility to water was measured using the water poverty index (WPI) method. WPI combines both the physical quantities relating to water availability and the socioeconomic factors relating to poverty to produce an indicator that addresses the diverse factors that affect water resource management [WRI, 2006]. The data required in this study include: sources of water supply in the study area, pattern and distribution of water, factors controlling access to water, community participation in water supplies among others. Water Poverty Index (WPI) was measured after Sullivan and Meigh. [2006] using data collected from households, in view of the shortcomings of WPI based on national data. This was done by collecting information on 5 indices, namely: resources, access, capacity, uses and environment.

The information required was obtained through the use of structured questionnaire. Each of these 5 components attracted a total score of $20 \%$, and will add up to $100 \%$. Hence, any community with a score of less than $50 \%$ may be regarded as water poor. 20 copies of questionnaire were administered per ward; this makes a total of 220 copies in which 220 households were sampled. The primary data were collected from the field (study area) through questionnaires and personal interviews.

The questionnaire is divided into two sections. Section A consists of primary attributes of respondents, while section $B$ comprises of water poverty index components: resources, access, capacity, uses and environment.

WPI value is a number between 0 and 100, where a low score indicates water poverty and a high score indicates good water provision. Each of these component indices is made up of sub-indices. Once all component indices have been calculated, they are added together, producing a value between 0 and 100. This value is the water poverty index [WRI, 2006].

\section{RESULTS}

\section{Primary attributes of respondents}

According to Table 1, about17.7 \% of the respondents are farmers, $25.9 \%$ are civil 
servants and $20.5 \%$ are traders. This shows that many of the respondents belong to the informal sector. Also, majority of the respondents had primary school education (37.3\%). While $22.7 \%$ attended secondary school education. Family size will affect the volume of water a household will use. Therefore, the larger the family sizes the more the quantity of water they consume. Family size ranges from 0 to $42.3 \%$ in the study area; family size of $3-5$ members and 6 -10 members were $42.3 \%$ respectively, Suggesting that family sizes in Irepodun L.G.A are generally fairly large. Income of majority of respondents (34.1\%) ranges between N7, 500and N10, 000 and also between less than N7, 500 per month (about33.6\%). These show that income of respondents is relatively low.

Table 1. Distribution of Respondents by Socio-Economic Characteristics.

\begin{tabular}{|c|c|c|c|c|}
\hline \multicolumn{5}{|c|}{ Occupation of the respondents } \\
\hline Wards & Trading & Farming & Civil Servant & Others \\
\hline Omu-Aran I & 5 & 2 & 4 & 9 \\
\hline Omu-Aran II & 7 & 3 & 3 & 7 \\
\hline Omu-Aran III & 3 & 3 & 7 & 7 \\
\hline Orol & 7 & 2 & 4 & 7 \\
\hline Oro $\|$ & 3 & 2 & 3 & 12 \\
\hline Ajaselpo I & 3 & 1 & 6 & 10 \\
\hline Ajaselpo II & 2 & 4 & 5 & 9 \\
\hline Esie/ljan & 3 & 2 & 8 & 7 \\
\hline Oko & 3 & 8 & 5 & 4 \\
\hline Arandun & 4 & 9 & 4 & 3 \\
\hline Ipetu/Rore/Aran Orin & 5 & 3 & 8 & 4 \\
\hline Total Percentage \% & $20.5 \%$ & $17.7 \%$ & $25.9 \%$ & $35.9 \%$ \\
\hline
\end{tabular}

Family Size of the respondents

\begin{tabular}{|l|c|c|c|c|}
\hline \multicolumn{1}{|c|}{ Wards } & $\mathbf{1 - 2}$ & $\mathbf{3 - 5}$ & $\mathbf{6 - 1 0}$ & ABOVE 10 \\
\hline Omu-Aran I & 2 & 6 & 12 & 0 \\
Omu-Aran II & 0 & 9 & 11 & 0 \\
Omu-Aran III & 1 & 11 & 8 & 0 \\
Oro I & 1 & 3 & 14 & 2 \\
Oro II & 3 & 6 & 10 & 1 \\
Ajaselpo I & 0 & 15 & 4 & 1 \\
Ajaselpo II & 0 & 15 & 4 & 1 \\
Esie/ljan & 0 & 9 & 7 & 4 \\
Oko & 7 & 3 & 9 & 1 \\
Arandun & 10 & 6 & 4 & 0 \\
Ipetu/Rore/Aran Orin & 0 & 10 & 10 & $4.5 \%$ \\
Total Percentage \% & $10.9 \%$ & $42.3 \%$ & $42.3 \%$ & \\
\hline
\end{tabular}




\begin{tabular}{|c|c|c|c|c|c|}
\hline \multicolumn{6}{|c|}{ Marital status of respondents } \\
\hline Wards & Single & Married & Divorced & Widow/Widower & Others \\
\hline Omu-Aran I & 6 & 12 & 0 & 1 & 1 \\
\hline Omu-Aran II & 6 & 10 & 1 & 1 & 2 \\
\hline Omu-Aran III & 4 & 9 & 2 & 3 & 2 \\
\hline Wards & Single & Married & Divorced & Widow/Widower & Others \\
\hline Orol & 3 & 10 & 2 & 4 & 1 \\
\hline Oro $\|$ & 5 & 9 & 1 & 4 & 1 \\
\hline Ajaselpo I & 9 & 10 & 0 & 1 & 0 \\
\hline Ajaselpo II & 6 & 11 & 1 & 1 & 1 \\
\hline Esie/ljan & 5 & 11 & 0 & 2 & 2 \\
\hline Oko & 8 & 8 & 0 & 2 & 2 \\
\hline Arandun & 4 & 12 & 0 & 2 & 2 \\
\hline Ipetu/Rore/Aran Orin & 4 & 13 & 0 & 2 & 1 \\
\hline Total Percentage \% & $27.3 \%$ & $52.3 \%$ & $3.2 \%$ & $10.5 \%$ & $6.82 \%$ \\
\hline \multicolumn{6}{|c|}{ Income level per month of respondents } \\
\hline WARDS & $\begin{array}{l}\text { LESS THAN } \\
\quad \mathbf{7 5 0 0}\end{array}$ & $\begin{array}{l}\text { N7,500- } \\
\text { N10,000 }\end{array}$ & $\begin{array}{l}\mathrm{N} 10,000 \\
-\mathrm{N} 15,000\end{array}$ & $\$ 15,000-\mathrm{A} 20,000$ & $\begin{array}{r}\text { ABOVE } \\
\text { N20,000 }\end{array}$ \\
\hline Omu-Aran I & 6 & 6 & 4 & 2 & 2 \\
\hline Omu-Aran II & 6 & 6 & 2 & 4 & 2 \\
\hline Omu-Aran III & 5 & 8 & 3 & 0 & 4 \\
\hline Orol & 3 & 11 & 2 & 2 & 2 \\
\hline Oro $\|$ & 7 & 6 & 2 & 0 & 5 \\
\hline Ajaselpo I & 10 & 5 & 1 & 1 & 3 \\
\hline Ajaselpo II & 7 & 7 & 3 & 2 & 1 \\
\hline Esie/ljan & 5 & 7 & 3 & 4 & 1 \\
\hline Oko & 10 & 6 & 1 & 2 & 1 \\
\hline Arandun & 12 & 4 & 2 & 0 & 2 \\
\hline Ipetu/Rore/Aran Orin & 3 & 9 & 3 & 4 & 1 \\
\hline Total Percentage \% & $33.6 \%$ & $34.1 \%$ & $11.8 \%$ & $9.5 \%$ & $11.0 \%$ \\
\hline
\end{tabular}


COMPONENTS OF WATER POVERTY

\section{Water resources}

Omu-Aran I is having the highest score (93.75\%), while Ajase-Ipo II has the least resource base (65 \%) (Table2.a). This is expected because Omu-Aran I is an LGA headquarter, it has the necessary infrastructure such as: pipe borne water, tarred roads, electricity, General Hospital, schools, etc unlike Ajase-Ipo II which is in the hinterland.

\section{Accessibility to Water Resources}

In terms of water resources Esie/ Ijan has the highest advantage having a score of $75 \%$ on access to water. Respondents in this ward have access to multiple sources of water; such as streams, hand dug wells, boreholes and pipe borne water. This ward has benefited from several self help projects in the area of water supply. Besides, most of the streams in this ward are still potable, in view of its relatively low population. Oko

Table 2(a). Water resources

\begin{tabular}{|c|l|c|c|c|c|c|c|}
\hline S/N & \multicolumn{1}{|c|}{ Wards } & $\begin{array}{c}\text { Major } \\
\text { Source of } \\
\text { Water } \\
\text { Supply (a) }\end{array}$ & $\begin{array}{c}\text { Alternative } \\
\text { Source of } \\
\text { Water (b) }\end{array}$ & $\begin{array}{c}\text { Differences } \\
\text { Between } \\
\text { Surface and } \\
\text { Groundwater } \\
\text { (c) }\end{array}$ & $\begin{array}{c}\text { Water } \\
\text { Supply } \\
\text { Quality (d) }\end{array}$ & $\begin{array}{c}\text { Subcomponent } \\
\text { (e) } \\
\text { (\%) }\end{array}$ & $\begin{array}{c}\text { (f) } \\
\text { (e/10) }\end{array}$ \\
\hline 1 & Omu-Aran I & 20 & 15 & 20 & 20 & 93.75 & 9.40 \\
2 & Omu-Aran li & 19 & 17 & 17 & 20 & 91.75 & 9.20 \\
3 & Omu-Aran lii & 19 & 15 & 13 & 17 & 80.00 & 8.00 \\
4 & Orol I & 18 & 17 & 17 & 19 & 88.75 & 8.87 \\
5 & Oro li & 19 & 13 & 14 & 20 & 82.5 & 8.25 \\
6 & Ajaselpo I & 20 & 15 & 15 & 20 & 87.5 & 8.75 \\
7 & Ajaselpo li & 20 & 6 & 6 & 20 & 65.00 & 6.50 \\
8 & Esie/jan & 20 & 15 & 15 & 20 & 87.5 & 8.75 \\
9 & Oko & 12 & 14 & 17 & 16 & 73.75 & 7.38 \\
10 & Arandun & 16 & 8 & 15 & 16 & 68.75 & 6.88 \\
11 & Ipetu/Rore/Aran Orin & 19 & 12 & 11 & 18 & 75.00 & 7.50 \\
\hline
\end{tabular}

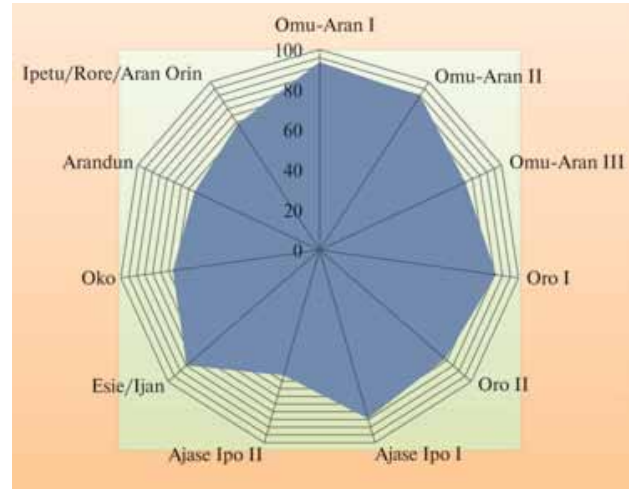

TFig. 2a. Distribution of Resource Per Ward

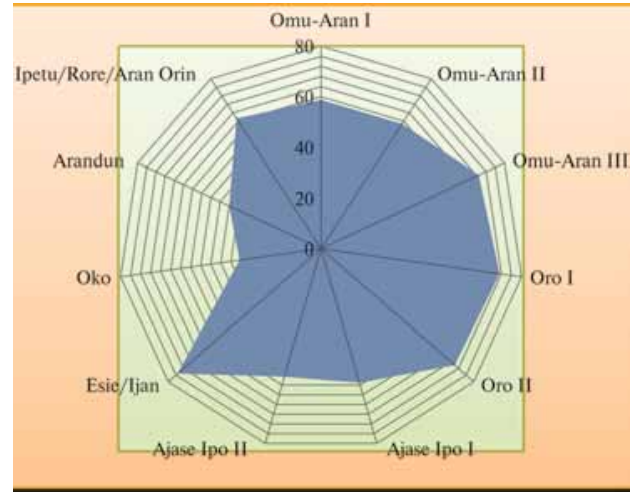

Fig 2b. Pattern of acess to water per ward 
Table 2(b). Accessibility to Water Resources

\begin{tabular}{|c|c|c|c|c|c|c|}
\hline \multirow{2}{*}{ S/N Wards } & \multirow{2}{*}{$\begin{array}{c}\text { Access } \\
\text { to Piped } \\
\text { Water } \\
\text { Supply (a) }\end{array}$} & \multirow{2}{*}{$\begin{array}{c}\text { Conflict } \\
\text { Over Water } \\
\text { Use (b) }\end{array}$} & \multirow{2}{*}{$\begin{array}{c}\text { Sanitation } \\
\text { (c) }\end{array}$} & \multirow{2}{*}{$\begin{array}{l}\text { Specific Time } \\
\text { in Water } \\
\text { Collection (d) }\end{array}$} & \multicolumn{2}{|c|}{ Subcomponent } \\
\hline & & & & & $\begin{array}{l}(e) \\
(\%)\end{array}$ & $\begin{array}{c}(f) \\
(e / 10)\end{array}$ \\
\hline 1.Omu-Aran I & 13 & 6 & 18 & 10 & 58.75 & 5.88 \\
\hline 2.Omu-Aran li & 14 & 7 & 20 & 6 & 58.75 & 5.88 \\
\hline 3.Omu-Aran lii & 18 & 8 & 15 & 14 & 68.75 & 6.88 \\
\hline 4. Oro I & 17 & 12 & 15 & 13 & 71.25 & 7.13 \\
\hline 5.Oro li & 13 & 10 & 14 & 19 & 70 & 7.00 \\
\hline 6. Ajase Ipo I & 9 & 11 & 13 & 11 & 55 & 5.50 \\
\hline 7. Ajaselpo li & 0 & 16 & 14 & 12 & 52.5 & 5.25 \\
\hline 8. Esie/ljan & 12 & 12 & 19 & 17 & 75 & 7.50 \\
\hline 9. Oko & 1 & 7 & 10 & 8 & 32.5 & 3.25 \\
\hline 10.Arandun & 4 & 5 & 15 & 8 & 40 & 4.00 \\
\hline 11. Ipetu/Rore/Aran Orin & 7 & 11 & 14 & 17 & 61.25 & 6.25 \\
\hline
\end{tabular}

ward remains the least in terms of access; having $32.5 \%$ accessibility to water; it has the least access to sources of water having only hand-pump wells (Table 2b).

\section{Capacity for Empowerment}

The score of each ward on capacity is generally weak, with a maximum of $50 \%$ in Ipetu/Rore/Aran-Orin (Table 2c; Figure 2c).

Table 2(c). Capacity for Empowerment

\begin{tabular}{|c|c|c|c|c|c|c|}
\hline \multirow[t]{2}{*}{ S/N Wards } & \multirow{2}{*}{$\begin{array}{l}\text { Illness } \\
\text { (a) }\end{array}$} & \multirow{2}{*}{$\begin{array}{l}\text { Under five (5) } \\
\text { Mortality } \\
\text { Rate (b) }\end{array}$} & \multirow{2}{*}{$\begin{array}{l}\text { Educa- } \\
\text { tional } \\
\text { Level (c) }\end{array}$} & \multirow{2}{*}{$\begin{array}{c}\% \text { of Respondents } \\
\text { Receiving Pension } \\
\text { or Wages (d) }\end{array}$} & \multicolumn{2}{|c|}{ Subcomponent } \\
\hline & & & & & (e) $\%$ & (f) $(e / 10)$ \\
\hline 1. Omu-Aran I & 3 & 1 & 17 & 12 & 41.25 & 4.13 \\
\hline 2. Omu-Aran li & 6 & 1 & 20 & 7 & 42.50 & 4.25 \\
\hline 3. Omu-Aran lii & 7 & 0 & 15 & 13 & 43.75 & 4.37 \\
\hline 4. Orol & 7 & 1 & 6 & 6 & 25.00 & 2.30 \\
\hline 5. Oro li & 8 & 0 & 16 & 5 & 36.25 & 3.63 \\
\hline 6. Ajase Ipo I & 7 & 1 & 17 & 4 & 36.25 & 3.63 \\
\hline 7. Ajase Ipo II & 8 & 1 & 12 & 4 & 31.25 & 3.12 \\
\hline 8. Esie/ljan & 8 & 1 & 16 & 6 & 38.75 & 3.88 \\
\hline 9. Oko & 3 & 0 & 9 & 5 & 21.25 & 2.12 \\
\hline 10. Arandun & 2 & 0 & 9 & 4 & 18.75 & 1.88 \\
\hline 11. Ipetu/Rore/Aran Orin & 9 & 5 & 18 & 8 & 50 & 5.00 \\
\hline
\end{tabular}




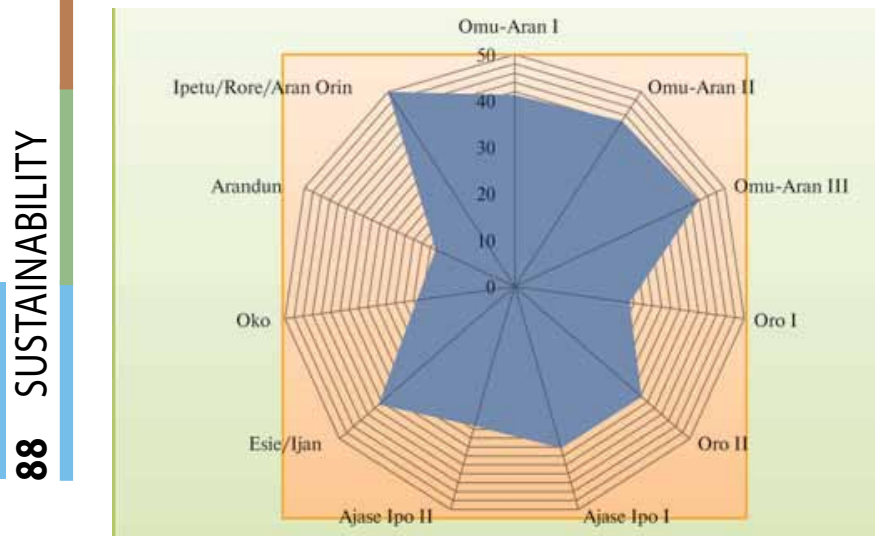

Fig. 2c. Pattern of respondent's capacity per ward
The least is found in Arandun ward with $18.75 \%$ capacity. The occupation dynamics of Ipetu/Rore/Aran-Orin ward is somehow complex, having an appreciable number of business people, civil servants and farmers who are empowered; also the level of income in this ward is the highest ranging between 7,500 to 10,000 naira.

Table 2(d). Water Uses

\begin{tabular}{|c|c|c|c|c|c|c|}
\hline \multirow{2}{*}{ S/N Wards } & \multirow{2}{*}{$\begin{array}{c}\text { Domestic } \\
\text { Uses (a) }\end{array}$} & \multirow{2}{*}{$\begin{array}{c}\text { Industrial } \\
\text { Uses (b) }\end{array}$} & \multirow{2}{*}{$\begin{array}{l}\text { Agricultural } \\
\text { Uses (c) }\end{array}$} & \multirow{2}{*}{$\begin{array}{c}\text { Livestock } \\
\text { Uses (d) }\end{array}$} & \multicolumn{2}{|c|}{ Subcomponent } \\
\hline & & & & & (e) (\%) & (f) $(e / 10)$ \\
\hline 1. Omu-Aran I & 20 & 3 & 2 & 16 & 51.25 & 5.13 \\
\hline 2. Omu-Aran li & 20 & 3 & 8 & 16 & 58.75 & 5.88 \\
\hline 3. Omu-Aran lii & 20 & 2 & 5 & 17 & 55.00 & 5.50 \\
\hline 4. Orol & 20 & 1 & 3 & 13 & 46.25 & 4.63 \\
\hline 5. Oro li & 20 & 1 & 3 & 13 & 46.25 & 4.63 \\
\hline 6. Ajaselpo I & 20 & 1 & 2 & 16 & 48.75 & 4.88 \\
\hline 7. Ajaselpo li & 20 & 1 & 4 & 16 & 51.25 & 5.13 \\
\hline 8. Esie/ljan & 20 & 1 & 3 & 19 & 53.75 & 5.38 \\
\hline 9. Oko & 20 & 9 & 8 & 10 & 58.75 & 5.90 \\
\hline 10. Arandun & 20 & 8 & 10 & 12 & 62.50 & 6.25 \\
\hline 11. Ipetu/Rore/Aran Orin & 20 & 4 & 8 & 16 & 60.00 & 6.00 \\
\hline
\end{tabular}

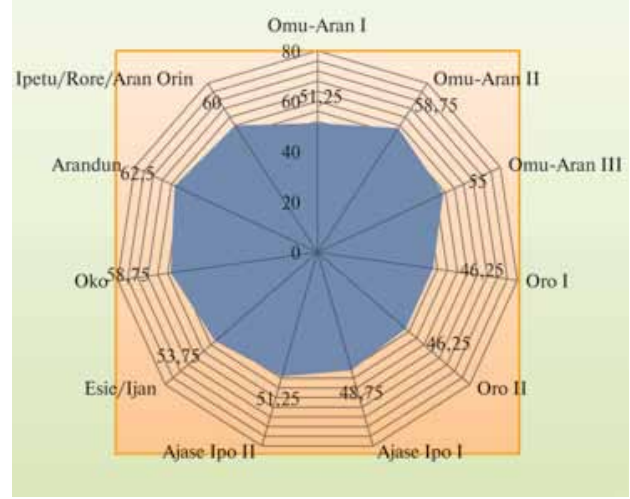

Fig. 2d. Pattern of water use per ward

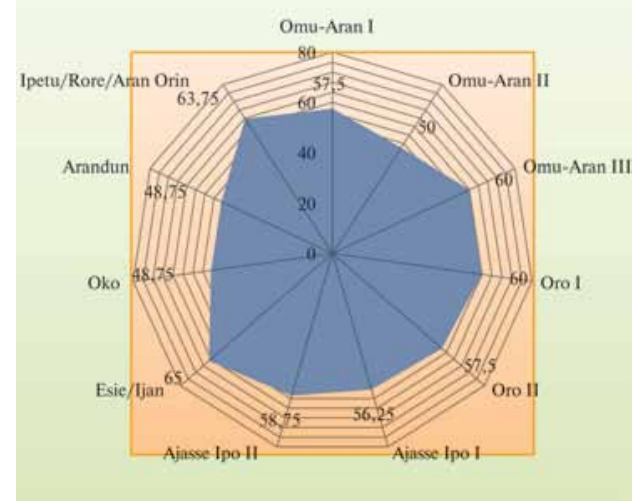

Fig. 2e. Pattern of environmental sub component 
Table 2(e). Respondents' Environment

\begin{tabular}{|c|c|c|c|c|c|c|}
\hline \multirow{2}{*}{ S/N Wards } & \multirow{2}{*}{ Pollution (a) } & \multirow{2}{*}{$\begin{array}{l}\text { Crop Loss in } \\
\text { the Last Five } \\
\text { (5) Years (b) }\end{array}$} & \multirow{2}{*}{$\begin{array}{l}\text { Erosion } \\
\quad \text { (c) }\end{array}$} & \multirow{2}{*}{$\begin{array}{l}\text { Environmental } \\
\text { Regulation and } \\
\text { Management (d) }\end{array}$} & \multicolumn{2}{|c|}{ Subcomponent } \\
\hline & & & & & (e) (\%) & (f) $(e / 10)$ \\
\hline 1. Omu-Aran I & 14 & 2 & 10 & 20 & 57.5 & 5.75 \\
\hline 2. Omu-Aranii & 4 & 2 & 14 & 20 & 50.0 & 5.00 \\
\hline 3. Omu-Aran lii & 14 & 4 & 10 & 20 & 60.0 & 6.00 \\
\hline 4. Oro I & 11 & 1 & 16 & 20 & 60.0 & 6.00 \\
\hline 5. Oro li & 12 & 0 & 11 & 20 & 57.5 & 5.75 \\
\hline 6. Ajase Ipo I & 13 & 1 & 11 & 20 & 56.25 & 5.63 \\
\hline 7. Ajase Ipo li & 16 & 3 & 11 & 17 & 58.75 & 5.88 \\
\hline 8. Esie/ljan & 17 & 1 & 14 & 20 & 65.0 & 6.50 \\
\hline 9. Oko & 6 & 8 & 9 & 16 & 48.75 & 4.87 \\
\hline 10. Arandun & 7 & 10 & 12 & 16 & 48.75 & 4.88 \\
\hline 11. Ipetu/Rore/Aran Orin & 13 & 6 & 13 & 19 & 63.75 & 6.38 \\
\hline
\end{tabular}

\section{Pattern of Water Use}

Water in the study area is mainly used for domestic purposes, water use is largely rural. Water related industries such as a few block and sachet water industries can be found. Livestock watering is also common. Arandun ward recorded the highest score in terms of uses with $62.5 \%$, while Oro I has $46.25 \%$ (Table $2 \mathrm{~d}$; Figure 2d). This implies that Arandun ward uses water for other purposes than domestic purposes, such as block making and irrigation agriculture (marketing gardening).

\section{Nature of Respondents' Environment}

According to Table 2(e), all the wards are exposed to on environmental problem or the other. Esie/ljan ward scored $65 \%$, while Oko and Arandun wards have $48.75 \%$ respectively (Figure $2(\mathrm{e})$ ).

\section{WATER POVERTY INDICES (WPI)}

According to Table 3 and Figure 3(a and b), Esie/ljan ward has the highest WPI, having highest score in resources (87.5\%), access (75\%) and environment (65\%) and WPI of $64 \%$; suggesting an advantage over others. Oko ward has the least WPI of $47 \%$, with least scores on access (32.5\%), capacity (21.25\%) and environment (48.75\%).
A comparative analyses of the WPI components show that resources has the highest score in all the communities, while capacity remain the least in all the wards. The high score recorded by resources is expected in view of the relatively high mean annual rainfall of about $1,500 \mathrm{~mm}$ which produced a minimum length of rainy season of about 6 months. Hence, the area has also benefited immensely from the relatively deep weathering which has provided a regolith aquifer for boreholes in this region. Deep weathering has been discovered in parts of the study. Furthermore, the study area has been at the fore front of self help projects.

\section{PROBLEMS OF WATER SUPPLY}

A number of problems are facing water resources development in Irepodun LGA. Some of these are discussed below.

i. Low capacity of water treatment facility in government water works: This is a common problem confronting water supply in Irepodun Local Government, as there is no ward experiencing daily water supply from the State Water Corporation due to the small sizes of treatment plants in the few settlements with public water supply particularly, Oro, Ajase-Ipo and Omu-Aran. This results in water shortages in these towns. 


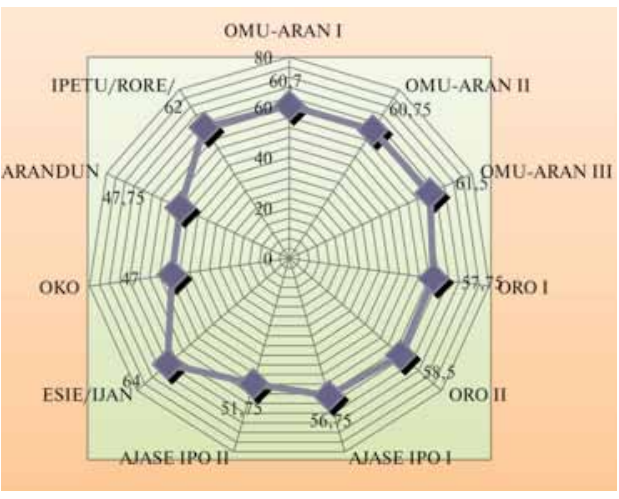

Fig. 3a. Water Poverty Indices (WPI) according to wards

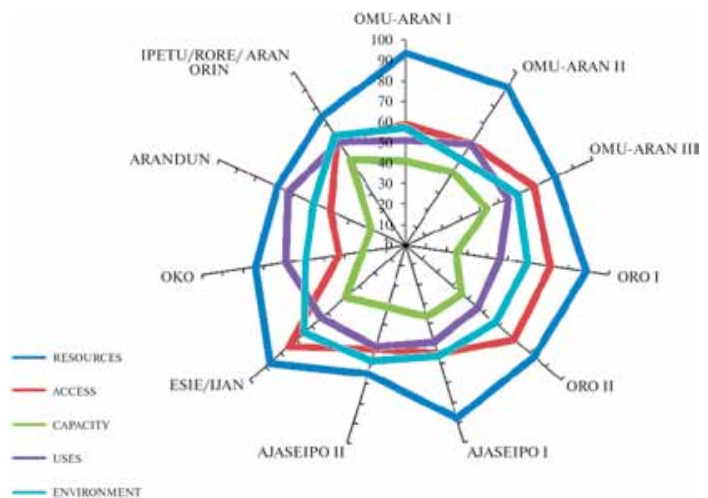

Fig. 3(b): Water Poverty Indices (WPI)

Table 3. Water poverty Indices (WPI)

\begin{tabular}{|c|c|c|c|c|c|c|c|c|}
\hline \multirow{3}{*}{$\begin{array}{l}\text { Wards } \\
\text { Ajase-|po I }\end{array}$} & \multirow{3}{*}{$\begin{array}{c}\begin{array}{c}\text { Re- } \\
\text { sources }\end{array} \\
87.50\end{array}$} & \multirow{3}{*}{$\begin{array}{l}\text { Access } \\
55.00\end{array}$} & \multirow{3}{*}{$\begin{array}{c}\text { Capacity } \\
36.25\end{array}$} & \multirow{3}{*}{$\begin{array}{l}\text { Uses } \\
48.75\end{array}$} & \multirow{3}{*}{$\begin{array}{c}\begin{array}{c}\text { Envi- } \\
\text { ron- } \\
\text { ment }\end{array} \\
56.25\end{array}$} & \multicolumn{3}{|c|}{ WPI ( \%) } \\
\hline & & & & & & \multirow{2}{*}{$\begin{array}{c}\begin{array}{c}\text { Irepodun } \\
\text { LGA }\end{array} \\
56.75\end{array}$} & \multicolumn{2}{|c|}{ Countries } \\
\hline & & & & & & & USA & 65.0 \\
\hline Ajase-Ipo II & 65.00 & 52.50 & 31.25 & 51.25 & 58.75 & 51.75 & Sri Lanka & 56.2 \\
\hline Arandun & 68.75 & 40.00 & 18.75 & 62.50 & 48.75 & 47.75 & $\begin{array}{l}\text { United } \\
\text { Kingdom }\end{array}$ & 71.5 \\
\hline Esie/ljan & 87.50 & 75.00 & 38.75 & 53.75 & 65.00 & 64.00 & Rwanda & 39.4 \\
\hline Ipetu/Rore/Aran Orin & 75.00 & 61.25 & 50.00 & 60.00 & 63.75 & 62.00 & Russia & $63, .4$ \\
\hline Oko & 73.75 & 32.50 & 21.25 & 58.75 & 48.75 & 47.00 & Sweden & 72.4 \\
\hline Omu-Aran I & 93.75 & 58.75 & 41.25 & 51.25 & 57.50 & 60.70 & Benin & 39.3 \\
\hline Omu-Aran II & 91.75 & 58.75 & 42.50 & 58.75 & 50.00 & 60.75 & Burkina Faso & 41.3 \\
\hline Omu-Aran III & 80.00 & 68.75 & 43.75 & 55.00 & 60.00 & 61.50 & Togo & 46.0 \\
\hline Oro I & 88.75 & 71.25 & 25.00 & 46.25 & 60.00 & 57.75 & Nigeria & 43.9 \\
\hline Oro II & 82.50 & 70.00 & 36.25 & 46.25 & 57.50 & 58.50 & Niger & 35.2 \\
\hline
\end{tabular}

ii. Faulty Taps and Pipes: Some of the public water taps in the study area are worn-out due to poor maintenance; hence, water is constantly wasted, especially inOmuAranWard I and II, Oro I andAjaselpo II.

iii. Poor Maintenance of Water Infrastructure: Some boreholes are no longer functional for lack of servicing atlpetu/Rore/Aran Orin and Arandun wards.

iv. Power Failure: The problem of power failure affects the process of treatment and water pumping for distribution. This is a common problem in Ajaselpo II, Esie/ljan and Oro II ward.

v. Long Queue: In places with public water taps, there is the problem of long queue due to high pressure around Ipetu/Rore/ Aran Orin, Omu-Aran I and III, Oro II and Esie/ljan ward.

\section{DISCUSSION}

The wards of the study area have strong scores on resources ranging from $68 \%$ in Arandun to $93 \%$ in Omu-Aran. This suggests 
that these communities are endowed. They have more than one source of water. The climate of the study area is humid tropical continental with about 6 months of rainy season, where mean annual rainfall is about $1,500 \mathrm{~mm}$. In fact, the LGA has one of the highest MAR in Kwara state, this quantity of rain gives rise to forested vegetation Omu-Aran, Arandun, Ajese-Ipo, Aran-Orin, etc. water sources is another dominant variable. Oro and Esie wards scored 70 and $71 \%$ respectively in this regards. These wards have shorter times of water collection. These communities have several hand pumps and hand dug wells, these wards are also contagious. They also have the highest numbers of community self-help projects in the LGA. They have very strong town development associations whose existence dated over 50 years back. Oko has the least water points because; it has only one water source, which is borehole.

As regards capacity, all the wards have weak scores. This is expected in rural areas in view of the few opportunities which abound. Ipetu/Rore/Aran-orin ward has the highest score on capacity. This ward is renowned for agriculture, particularly vegetable business; it has the highest income range, and has more than one occupation type. Omu_Aran wards which serve as the LGA headquarter also have relatively high capacity. Generally, capacity is weak in the LGA. This is an indication of widespread poverty which is typical of many Nigeria rural communities. This will affect capacities to buy water, for water use and accessibility to water. Only 2 LGAs namely: Oko and Arandun wards can be regarded as water poor, all other wards have above average scores. However, this is not to say that these wards have strong scores. Indeed, water resources in these wards still needed some level of intervention, in view of the fact that these seemingly high scores are mainly due to available resource of the relatively high mean annual rainfall coupled with the efforts of various Community Based Associations (CBA) which is typical of Kwara south senatorial area where existence of some CBAs and Town Unions dated back into about 100 years. Hence, there is need for government and public- private efforts with some of the CBAs in water provision. More importantly there is need for government intervention in Oko and Arandun wards with low capacities and low scores on sources of water, these is because a breakdown or contamination of the singular source of water to these communities will wreck havoc, as locals will have low capacity to explore alternative sources of water.

A comparison of WPI values for Nigeria (43.9\%) with the values obtained in this study for Irepodun LGAs (ranging between $47 \%$ in Oko to $64 \%$ in Esie/ljan ward) shows that WPI in Irepodun is greater than the national average for Nigeria. In the same vein, a comparison of the values presented by Lawrence, et. al [2002] indicated that WPI value for Nigeria is higher than what obtains in some African countries such as Rwanda, Benin, Burkina Faso, Togo and Niger republic. However, there is still need for improvement on the part of the relevant tiers of government at improving water access in the study area.

\section{CONCLUSION}

The results show that resources have the highest value in terms of percentage which means respondents have more than one or two sources of water supply. Also, capacity has least score throughout suggesting that poverty is widespread in the LGA.

However, rural water supply is relatively above average as many of the communities have WPI values above average apart from Oko and Arandun which have values below average. The relatively strong value of WPI is in view of the strong base of resources which manifest in form of relatively high MAR of about $1,600 \mathrm{~mm}$, which translate to 6 months of rainfall, this has made water available and also 
in view of the widespread community based efforts in many of communities. Hence, government still needs to double its efforts. However, intervention is required in Oko and Arandun, where WPI are low. These communities have low capacities and fewer sources of water, this is necessary in view of their weak capacity to seek for alternative sources of water, especially in situations of diseases outbreak.

\section{REFERENCES}

1. Ahmad, Q. K. (2003). Towards poverty alleviation; The Water sector prospective. Water Resources Development, 19 (2), 263-277.

2. Alcamo, J., Doll, P., Kaspar, F. and Siebert, S. (1997). Global Change and Global Scenarios of Water Use and Availability: An Application of Water GAP1.0. Center for Environmental Systems Research (CESR), University of Kassel, Kassel, Germany.

3. Ashton P.J. (2002) Avoiding conflicts over Africa's water resources. Ambio, 31 (3): 236-242.

4. Ashton, P.J. (2007). Disputes and conflicts over water in Africa in: Violent Conflicts, Fragile Peace: Perspectives on Africa's Security, (N. Mlambo, Ed.). London: Adonis and Abbey.

5. Asian Development Bank (2000). Water for All: The Water policy of the Asian Development Bank Manila, Asian Development Bank.

6. Earth Summit Watch (2001) Clearing the water: A paradigm for providing the world's growing population with safe drinking water. Earth Summit Publications.

7. Falt, C. (2003).Alternatives to GDP. Available at: http://www.trytel.com/ cfalt/GPI/

8. Kleiner SM.(1999) Water: An essential but overlooked nutrient. Journal of the American Dietetic Association. 99:200-206.

9. Lawrence, P., Meigh, J. and Sullivan, C., (2002). The Water Poverty Index: an International Comparison. Department of Economics Keele University, Keele, Staffordshire, United Kingdom.

10. Madaleen W.S (2001) Water demand and management and the poor IRC International Water Sanitation Press.

11. Molden, D. (1997) Accounting for Water Use and productivity. Colombo, International Irrigation Management Institute.

12. Molle, F., and Mollinga, P. (2003) Water poverty indicators: Conceptual problems and policy issues, Water Policy 5: 529-544.

13. NWRS, (2004).National Water Resources Strategy.The Department of Water Affairs and Forestry, Pretoria, South Africa.WRI, 2006. World Resources institute. Water Resources and Freshwater Ecosystems — Freshwater Indices: Water Poverty Index, Technical Notes. http://earthtrends.wri.org/text/water-resources/variable-1299.html 
14. Peter L.J, Meigh and Sullivan, C. The water poverty index an international comparison Kaale Economics Research Papers October 2002.

15. Rennie, K. and Singh, N. (1996) Participatory Research for Sustainable Livelihoods: a Guidebook for Field Projects. International Institute for Sustainable Development, Manitoba, Canada.

16. Seckler, D., Amarasinghe, U., Molden, D., De Silva, R. and Barker, R. (1998) World Water Demand and Supply, 1990 to 2025:Scenarios and Issues. IIMI Research Report 19. IIMI, Colombo, Sri Lanka.

17. Soussan, J., and D. Frans. (2003) The role of water in the development of sustainable livelihoods of the poor. In: Asian Development Bank, Water and Poverty - A collection of Thematic Papers. Prepared by: Water and Poverty Initiative for the 3World Water Forum held in Kyoto, Shiga and Osaka, Japan, 16-23 March, 2003. Asian Development Bank, pp. 83-91.

18. Sullivan, C. 2002. Calculating a Water Poverty Index. World Development.30 (7): 11951210. Elsevier Science Ltd, Great Britain.

19. Sullivan, C.A., Meigh, J.R., and Fediw, T.S., (2002).Derivation and Testing of the Water Poverty Index Phase 1.Centre for Ecology and Hydrology, Wallingford, United Kingdom.

20. Sullivan, S. and Meigh, J. (2006) Application of the Water Poverty Index at different scales: A cautionary tale. Water International 31 (3): 412-426.

21. UN WATER (2006) Coping with water scarcity. A strategic issue and priority for systemwide, http// www.unwater.org/waterscarcitypdf

22. W.H.O. (2008) Safe water, better health.Cost, benefits and sustainability of interventions to protect and promote health). Annette prus-Ustun(et al). http//www.unwater.org/ waterscarcitypdf

23. W.H.O/UNICEF (2000) Global Water Supply and Sanitation Assessment WHO/UNICEF; Geneva 2000.

24. Water facts (2011) Millions lack safe water http://water.org/water-crisis/water-facts/water/

25. WaterAid (2012) UK Annual Review2011/12 WaterAid,47 - 49 Durham Street, LondonSE11 5JD Telephone 02077934594 Fax 02077934545 www.wateraid.org

26. WCED (1987). Report of the World Commission on Environment and Development: "Our Common Future Development and International Economic Co-operation: Environment. United Nations.

27. World Bank (1993) Water resources Management: Executive Summary.Washington D. C. World Bank.

28. World Bank (2001) World Development Report 2001/2002: Attacking poverty, Oxford University Press. 